\title{
The Anglosphere in the Brexit Referendum
}

L'Anglosphère dans le référendum sur le Brexit

\section{Ben Wellings}

\section{(2) OpenEdition}

\section{Journals}

Electronic version

URL: http://journals.openedition.org/rfcb/1354

DOI: $10.4000 /$ rfcb.1354

ISSN: 2429-4373

\section{Publisher}

CRECIB - Centre de recherche et d'études en civilisation britannique

\section{Electronic reference}

Ben Wellings, "The Anglosphere in the Brexit Referendum », Revue Française de Civilisation Britannique [Online], XXII-2 | 2017, Online since 30 May 2017, connection on 30 April 2019. URL : http:// journals.openedition.org/rfcb/1354; DOI : 10.4000/rfcb.1354

This text was automatically generated on 30 April 2019.

Revue française de civilisation britannique est mis à disposition selon les termes de la licence Creative Commons Attribution - Pas d'Utilisation Commerciale - Pas de Modification 4.0 International. 


\title{
The Anglosphere in the Brexit Referendum
}

\author{
L'Anglosphère dans le référendum sur le Brexit
}

Ben Wellings

1 This article examines the place of the 'Anglosphere' in the UK's referendum on membership of the European Union in 2016. It analyses how arguments about the United Kingdom's relationship with the EU and its place in the world were framed within ideas about Britain's past and present relationship with other English-speaking peoples. This article will first examine the place of the Anglosphere as an idea within British politics during the referendum campaign. It will then look at each of the 'core' Anglosphere states that featured prominently during the campaign. To that end it will focus on the place of the USA, Australia and Canada (and to a lesser extent New Zealand). Although during the campaign the Anglosphere appeared less as a discrete concept and more in its constituent parts - especially the USA, Australia and Canada - this article concludes that the Anglosphere was one of the surprise winners of the 2016 referendum and the re-ordering of Britain's place in the world that followed.

\section{The Anglosphere: a love that dare not speak its name}

2 If the 2003 invasion of Iraq was the Anglosphere first outing in international relations, then the 2016 Brexit referendum was its first big test in domestic politics. The salience of this idea and its constituent elements forces us to reject outright the idea that 'Leave' campaigners were "Little Englanders". Far from it: the ideologues were not intent of turning the United Kingdom into 'Guernsey' as Emmanuel Macron put it, ${ }^{1}$ but were intent on returning the United Kingdom to what they saw as a pre-EU global field of action.

The Anglosphere made an official appearance in domestic UK politics prior to the Brexit referendum. In 2015 the UK Independence Party cited it in their 2015 General Election Manifesto. "Britain is not merely a European country" claimed UKIP, "but part of a global community, the Anglosphere". The manifesto continued: 
Beyond the EU and even the Commonwealth are a network of nations that share not merely our language but our common law, democratic traditions and global trading interests. From India to the United States, New Zealand to the Caribbean, UKIP would want to foster closer ties with the Anglosphere. ${ }^{2}$

Following the Conservative's general election win in May 2015, UKIP published a report entitled Out of the EU and Into the World (an echo of the Anti-Marketeers' campaign slogan from the 1975 referendum campaign). ${ }^{3}$ Limbering up for the Brexit referendum in 2016, UKIP member Andrew Cadman weighed up some of the alternatives to membership of the $\mathrm{EU}$ and noted that "Sadly, strengthening our ties with the Commonwealth is too easily caricatured as a Colonel Blimp hankering after the past, and the institution is probably too freighted with historical baggage, not least Britain's callous betrayal of its ex-colonies when it joined the EU". As a result he concluded that "A better bet would be a formal Anglosphere club of Commonwealth members, the United States and Ireland". ${ }^{4}$

But enthusiasm for the Anglosphere was not just to be found amongst UKIP members. At the outset of the referendum campaign in February 2016 the one-time leadership hopeful who lost out to David Cameron in 2005, David Davis, made the Anglosphere an integral part of his vision for Britain outside of Europe. "We must see Brexit as a great opportunity to refocus our economy on global, rather than regional, trade" he argued in a speech subsequently posted on Conservative Home:

This is an opportunity to renew our strong relationships with Commonwealth and Anglosphere countries. These parts of the world are growing faster than Europe. We share history, culture and language. We have family ties. We even share similar legal systems. The usual barriers to trade are largely absent. The Prime Minister has repeatedly stated that we are a trading nation with global horizons. This is undoubtedly true. So it is time we unshackled ourselves, and began to focus policy on trading with the wider world, rather than just within Europe. ${ }^{5}$

Davis' vision was grounded in the free trade traditions of the English-speaking countries. The other major strand that Anglosphere enthusiasts claimed linked the English-speaking countries was political. It was this political commonality that underpinned Michael Gove's foray into Anglosphere territory as he announced his decision to back the Leave campaign in February 2016. Gove argued that "Instead of grumbling and complaining about the things we can't change and growing resentful and bitter, we can shape an optimistic, forward-looking and genuinely internationalist alternative to the path the EU is going down". He concluded that "Like the Americans who declared their independence and never looked back, we can become an exemplar of what an inclusive, open and innovative democracy can achieve". 6

Gove's intervention illustrated the way that Anglosphere countries operated as models for other Anglosphere nations and the way that such claims carried a legitimacy that did not need explanation or elaboration in the way that aligning England and the United Kingdom with European countries did. But it also illustrated the way that [at the elite level] the Anglosphere was a love that dare not speak its name, because it was seldom referred to explicitly during the referendum campaign. Indeed there was significant pushback from within the very Anglophone countries that were supposed to form the basis of a post-EU Britain's new world order. Speaking in Munich in February 2016 US Secretary of State John Kerry reminded his audience of US policy towards Britain and Europe since the very beginnings of the process of European integration in the early stages of the Cold War: "the United States has a profound interest in your success as we do in a very strong United Kingdom staying in a strong EU".? 
Leaders of the other three Anglosphere states reinforced this view. Canadian Prime Minister Justin Trudeau argued from first principles that "I believe that we're always better when we work as closely as possible together, and separatism or division just doesn't seem to be a productive path for countries". ${ }^{8}$ From a more instrumental point of view, New Zealand Prime Minister John Key added New Zealand's support for David Cameron's attempt to keep Britain in the EU during a Washington summit in April 2016. Key said: "If we had the equivalent of Europe on our doorstep... we certainly wouldn't be looking to leave it". ${ }^{9}$ Australian Prime Minister Malcolm Turnbull echoed this international consensus, repeating in May 2016 the Australian government's position that had been outlined during the UK's "Balance of Competencies" review three years previously:

We welcome Britain's strong role in Europe. The EU is an enormous economic and political entity and from our point of view - you might say from our selfish point of view - having a country to whom we have close ties and such strong relationships... is definitely an advantage. ${ }^{10}$

9 Such support from international leaders was seized upon by the Remain campaign in a doomed attempt to suggest that Britain would find itself isolated outside of the EU in a hostile world (a re-run of an argument from the 1975 referendum). Foreign Secretary Philip Hammond said that international support for the UK to remain underlined "the simple fact that our Commonwealth partners see Britain as being stronger and more influential as a member of the EU". From this he concluded that "it would be dangerous and arrogant to dismiss out of hand the concerns and feelings of some of our closest and oldest allies, partners with whom we share so much history and heritage, and with whom we work so closely on trade, defence and security". ${ }^{11}$ Endorsing John Kerry's argument in Munich, Britain Stronger In Europe executive director Will Straw said Kerry's comments reinforced how staying in the EU enhanced Britain's global influence: "Being in an alliance with 27 other European democracies strengthens our hand when dealing with threats like terrorism and a resurgent Russia. And increases our clout and credibility in Washington".12

10 Harsher judgments were reserved for the concept of the Anglosphere itself, which revealed tensions within the policy communities of the core Anglophone states. John Key's endorsement of British membership of the EU came despite tensions over increasing visa restrictions for New Zealand nationals seeking to enter and remain in the UK that took effect on 6 April 2016 resulting in numbers falling from about 18,000 in 2000 to 8,500 in 2014. ${ }^{13}$ The Australian Foreign Minister, Julie Bishop, dismissed the idea of the Anglosphere as a fantasy, ${ }^{14}$ whereas former foreign secretary Gareth Evans described the idea as an illusion. ${ }^{15}$

11 Given this hostility, the Anglosphere played little part in the national debate from February to June 2016 as a named concept. Instead the Anglosphere's most frequent invocations during the referendum were made in the form of its discrete components. These included the adoption of what was called an 'Australian-style points-based immigration system', using the Canada-EU Free Trade Agreement signed in 2015 as a model for the UK's new economic relations with the world and - in a negative sense - the intervention of the US President Barak Obama. 


\section{"Over Here": the American Intervention}

12 Remain deployed its big guns early on in the campaign. In a trip to Europe to visit the UK and Germany, Barak Obama lent his support to the campaign to keep Britain in the EU. Speaking to his audience in a version of English they could understand, Obama stated clearly that a non-EU United Kingdom would be "at the back of the queue" (rather than "line") when it came to negotiating a free trade agreement with the USA. Prior to this Obama had argued that the UK's EU membership gave the US "much greater confidence about the strength of the transatlantic union". ${ }^{16}$

13 Such support was not surprising for two main reasons. The first was that close British collaboration with continental Europe had been a goal of US policy since the Marshall Plan was launched in 1948. The US State Department had always been keen on British involvement in the process of European integration and Obama was not going to change that policy. The second reason was because the US was already negotiating a free trade agreement with the EU - the Trans-Atlantic Trade and Investment Partnership (TTIP) and having a new arrival on the scene would only complicate matters, in just the same way that a Brexit would complicate CETA and the Australia-EU FTA agreed upon in November 2015.

But the response to Obama's interventions in 2015 and 2016 revealed some of the tensions within the idea of the Anglosphere and the way that the pasts of Anglosphere countries, particularly the American Revolution, could be deployed in support of Brexit. Former Environment Secretary Owen Paterson, a leading Eurosceptic backbencher, noted that two centuries ago the Americans "fought not to have laws imposed on them so I don't think [Obama's] in a strong position when we want to make our own laws in our own Parliament". Patterson continued that "It is massively in America's interest that a strong UK, using all its contacts in the Anglosphere, with Canada, New Zealand and Asia regalvanises the movement for world free trade that would be massively positive for thousands of people". ${ }^{17}$

Important here was the idea that supporting the Anglosphere does not mean adherence to the Washington line. The right of British politics had hitherto been the foremost defending of the "Special Relationship", leaving criticism of that alliance to the left. But in this instance the Eurosceptic Anglosphere enthusiasts took their cue from the right of the Republican Party and US neo-conservatives. After Obama had said that Britain would be at "the back of the queue" for any FTA negotiations, Republican presidential candidates, Ted Cruz and Mark Rubio suggested otherwise. Ted Cruz argued in response:

Instead of standing with our allies President Obama routinely hurls insults at them. Sadly, it happened in London last Friday, when the President of the United States informed the British people they would be at the "back of the queue" for a US-UK free trade deal if they dared to vote to leave the EU on June 23. This was nothing less than a slap in the face of British self-determination as the president, typically, elevated an international organisation over the rights of a sovereign people. ${ }^{18}$

Donald Trump was unusually circumspect about Brexit, but he did endorse the result after the fact. But even his intervention could not outdo Boris Johnson's suggestion in The Sun that "the part-Kenyan President's ancestral dislike of the British empire" meant that he wanted to see the UK diminished by retaining its membership of the EU. ${ }^{19}$ This incident was freighted with historical baggage and illustrated an anxiety about a 
weakening of the Anglo-US "Special Relationship". On assuming office in 2009 Obama allegedly moved a bust of Winston Churchill - presented by Tony Blair to George W Bush - out of the Oval Office. Kenya was the site of "Britain's gulag" during the Mau Mau rebellion of the 1950s and had been a source of sharp political division in Britain in 1959 when a young MP named Enoch Powell spoke out against conditions in the Hola concentration camp. Memory of Empire was just below the surface for the proAnglosphere Brexit campaigners. But it would be wrong to see this as simple nostalgia. Britain's past greatness was a source of mobilising inspiration for its future. ${ }^{20}$ The Anglosphere and the Commonwealth and Imperial traditions in British foreign policy and national identity were not just a place of departure for a critique of Britain's place in the $\mathrm{EU}$, but a crucial element in imagining a "global Britain". In this worldview EU membership was a mere interregnum in Britain's global history.

\section{"Girt by Sea": an Australian-style points-based immigration system}

Malcolm Turnbull's endorsement of Bremain outlined above did not go unnoticed during the referendum campaign. Turnbull's support for Britain in the EU was criticised by Brexiteer Andrew Rosindell, a member of the Foreign Affairs Select Committee, who rebutted Turnbull's position by asking the rhetorical questions: "Come on Malcolm, when are you going to do your political union with Indonesia or Japan? When are you going to have free movement with Asia? This is ridiculous".21

Thus the free movement of people was the place where Australia featured most prominently in the campaign. Early on, the Royal Commonwealth Society released a report that appeared to show support amongst Commonwealth citizens for a European Union-style system of free movement between the United Kingdom, Australia, Canada and New Zealand. $70 \%$ of Australians surveyed were in favour of the idea. Support was stronger still among Canadians (75\%) and New Zealanders (82\%) and people under the age of 35. The policy proposal was least popular in Britain, but even there $58 \%$ of those surveyed supported it. Vox-popped by the Australian Broadcasting Corporation (ABC) about the idea Jo McGregor, a barwoman from London, thought "Well I think if you observe history it seems only fair": "Why should people from Australia or New Zealand have a harder time [working in Britain] than people from Europe? We've got the same Queen, we fought the same wars, we have the same language and similar culture"..22

Boris Johnson had been pushing for such a zone of free movement for some years in his capacity as Mayor of London and Honorary Australian of the Year for 2014. Daniel Hannan also called for such an initiative in the days after the vote, a position consistent with his support for the Anglosphere. What the inhabitants of the Antipodes might have thought about 65 million Britons with the sudden opportunity to live and work in Australia and New Zealand was not canvassed.

But in another respect Australia played an important part in British exit from the EU. John Howard, Prime Minister of Australia from 1996-2007, publically backed Brexit during the campaign. "The European project is fundamentally flawed" he argued. "I think its best days are probably behind it... Britain can't control its borders - it is ridiculous to say it can. If I were British, which I'm not, I'd vote to leave. You have lost your sovereignty". ${ }^{23}$ Howard's term as Prime Minister was best known for his strong link between sovereignty 
and border control, precisely the issue that was such an important element of the Leave campaign's mass appeal.

Initially a UKIP election pledge subsequently adopted by Vote Leave, the deployment of the "Australian-style points-based immigration system" was an important part of the Brexit campaign's alternative to the current immigration system linked with the free movement of people within the European Union. Although the United Kingdom, along with Ireland, was not part of the Schengen Treaty that eliminated border controls within the other parts of the EU, the damaging link made between the free movement of labour and the movement of asylum seekers and refugees - especially after the summer of 2015 had already been made to good effect by UKIP since 2009.

Thus it was that Australia became an exemplar of what a post-Brexit Britain might be and do: "my ambition is not a Utopian ideal - it's an Australian reality" Michael Gove told an audience of Vote Leave supporters in April 2016.

Instead of a European open-door migration policy we could - if a future Government wanted it - have an Australian points-based migration policy. We could emulate that country's admirable record of taking in genuine refugees, giving a welcome to hardworking new citizens and building a successful multi-racial society without giving into people-smugglers, illegal migration or subversion of our borders. ${ }^{24}$

But immigration policy was often conflated with border protection and the issue of asylum seekers arriving by sea had been an intractable and divisive issue in Australia since John Howard won an election on border protection in 2001. Given the existence of "dog-whistle" politics on this issue in Australia and the accusations of such tactics having been levelled at the Conservative mayoral election campaign in May 2016, it was as much Australia's "Operation Sovereign Borders" as its points based immigration system to which Brexiteers were appealing. Speaking at the Margaret Thatcher Foundation, former Australian Prime Minister Tony Abbott warned that Angela Merkel and Jean-Claude Junker's approach to the Syrian refugee crisis was a "catastrophic error". Speaking about his Operation Sovereign Borders policy, Abbott told his audience that "stopping the flow of illegal immigrant boats" was important "because a country that can't control its borders starts to lose control of itself". ${ }^{25}$

Nor was this an issue of policy alone, but one of resonance too. The Brexiteers were not suggesting that any old country's immigration system be adopted, but one with strong historic ties to the UK. The historic appeal was picked up by some sceptical of the motives behind adopted Australian practice. The Guardian ran an op-ed when this policy was announced claiming that "the campaigning value of the Australian reference is obvious enough, though the campaign will deny it. It is a code for friendly white Anglo-Saxon people who speak English". ${ }^{26}$ But like Pauline Hanson's short-lived stay in the UK to where she moved to get away from Asians, this view shows little understanding of the post-imperial development of either Australia (or Britain in Hanson's case).

Once the 'purdah' period (a term with a suitably imperial lineage) began and the Remain camp could no longer draw on the resources of the civil service - resources that they overplayed in any case - immigration swung momentum the way of the Brexiteers. Like the Americans and their Revolution, another Anglosphere country - in this case Australia - provided a model for emulation in a post-EU Britain.

America and Australia were not the only Anglosphere countries to feature in the campaign. It should be remembered that there were two leave campaigns: Vote Leave and 
Leave.EU. The latter - backed up by Grassroots Out - were closely aligned with UKIP; the former with the Conservative Party. It was Vote Leave that was endorsed by the Electoral Commission as the official campaign in April 2016. UKIP posed a considerable threat to the Conservatives and was one of the reasons that David Cameron conceded a referendum to Eurosceptic backbenchers in January 2013. Despite tension between these two parties and campaigns, one thing they did agree on was free trade - or freer trade that they thought they were getting within the EU. This was where Canada came into the referendum campaign.

\section{"Strong and Free": the Canada-EU Comprehensive Economic and Trade Agreement (CETA)}

In the wake of the 2015 General Election and Brexit, it was clear that one of the few points of commonality shared between politicians in England and Scotland was a desire to be more like Norway. But this commonality was only skin-deep. Scots admired Norway's social democratic model, whereas English Eurosceptics tended to admire its access to the Single Market, the only thing about the EU that most of them liked. Iceland - the small nation responsible for England's second surprise exit from Europe within the week commencing 23 June - was also mooted as a model for the United Kingdom to emulate along with Switzerland and even Lichtenstein.

Yet before he began his negotiations with the EU (negotiations that The Sun likened to a Maori haka - understood in England as featuring a lot of posturing but with little of substance), David Cameron was at some pains to reject Norway and Iceland (the old EFTA model) as models for a reformed UK-EU relationship. During a visit to Reykjavik on 28 October 2015 and during subsequent Prime Minister's Questions on 28 October, Cameron set out his case. ${ }^{27}$ In response to a question from Christopher Pincher (Tamworth, Con) the Prime Minister said "Some people arguing for Britain to leave the European Union, although not all of them, have pointed out a position like that of Norway as a good outcome. I would guard strongly against that. Norway pays as much per head to the EU as we do and takes twice as many migrants per head as we do in this country, but has no seat at the table and no ability to negotiate". ${ }^{28}$

30 Likewise, Switzerland's relationship with the EU was initially rejected. In all of these ruminations there was always a feeling that somehow none of these countries were really great enough for Great Britain to emulate. There was one novel relationship between the $\mathrm{EU}$ and a third country that was suitably bound by language, culture and history and that was the Free Trade Agreement struck between the EU and Canada in 2015.

Canada's reputation went before it. Widely seen as a better if slightly more boring version of the United States, journalist Gabby Hinsliff described it as "like the solid but rather earnest man you realise too late that you actually should have married", but adding enviously that in the wake of Justin Trudeau's election in 2015 it was "still surfing a wave of sunny progressive feeling when the US and much of Europe are increasingly convulsed with rage against either poor migrants or privileged elites, or both". ${ }^{29}$

Eurosceptics had seized on Canada's understated charms too. Norman Lamont, Chancellor of the Exchequer at the time of the UK's exit from the European Exchange Rate Mechanism (ERM) in 1992 suggested that the EU-Canada Comprehensive Economic and Trade Agreement (CETA) (or "Canada+") would be a good model for the UK after a Brexit. 
He said a post-Brexit UK would have the same World Trade Organisation (WTO) means of trading with the EU as the USA or Australia. ${ }^{30}$ But Canada+ was especially attractive to Brexiteers who, with the small exception of Labour Leave, were all committed free traders. During the campaign it served as a model for the way that a post-EU UK would underpin its new economic relationships with the $\mathrm{EU}$ and the wider world.

Another country sometimes included in the Anglosphere, having adopted English as one of its four official languages in 1967, and which had recently concluded a free trade deal with the EU was Singapore. Like CETA, the EU-Singapore comprehensive free trade agreement was signed in October 2014 and was similarly jeopardised by Brexit. Despite this, the former British naval base turned global, financial entrepôt was also attractive to prominent Brexiteers as a model for Britain to emulate.

Douglas Carswell, UKIP's sole MP after the 2015 election is credited with coining the term "Singapore on steroids" to describe his vision of the United Kingdom outside of the EU. ${ }^{31}$ Although Carswell disputed this description, he certainly made comparisons to Singapore. Singapore fitted well with the Eurosceptic conception of Britain as a "world island" in Andrew Gamble's phrase: a strategically important hub and a bastion of free trade and neo-liberalism in the region. Yet in 2015 an estimated 29\% of Singapore's population of 5.5 million were non-permanent residents, ${ }^{32}$ a figure that would have jarred with the anti-immigration stances struck by certain Leave campaigners.

On the morning of 24 June the Leave leaders were as surprised as anyone to find themselves on the winning side of the result..$^{33}$ But an emphasis on the Anglosphere starts to shed light on the post-Brexit politics of the United Kingdom. Although Theresa May's speech outside of Downing Street on becoming Prime Minister was couched in terms of an inclusive One Nation Tory tradition, her choice of key ministers was a coup for Anglosphere enthusiasts. David Davis was appointed as Minster for Exiting the European Union, Liam Fox as Secretary for International Trade and Boris Johnson as Foreign Secretary. Similarly a YouGov poll conducted in September 2016 showed that the Anglosphere was high on the list of Leave voter's priorities when it came to making new trade deals, with the geographically distant Australia topping the list. ${ }^{34}$

36 All this allowed a certain amount of triumphalism amongst those who felt the EU represented a mis-alignment of Britain true allies and friends. "For years in Britain the idea of the Commonwealth looked marginal at best, eccentric at worst" wrote conservative ideologue Simon Heffer, describing it as "some sort of national consolation prize for having lost the British Empire" that "gave the Queen something to do". But Brexit changed this dispensation. As Heffer noted, "the Commonwealth started to assume an importance it had not had for more than 40 years". As Theresa May's new government began to focus on new directions the talk was of global trade, not just with the BRICS, but "with those nations with whom the British share ties of history, blood and language". ${ }^{35}$ It was these ties that won on 23 June.

It could be argued that the Anglosphere played a largely behind-the-scenes role in the Brexit referendum. But this is only true if we look for it as a unitary concept in support of arguments to leave the EU. Instead, three of the four "core" Anglosphere countries (excluding Britain and its history itself) featured prominently in the referendum campaign. Canada's Comprehensive Economic and Trade Agreement (CETA) with the EU was attractive to Brexiteers as a model for a new UK-EU trade relationship based on free trade. Australia's points-based immigration system (and its reputation for harsh border protection policies) fed into the both Leave campaigns' (Vote Leave and Leave.EU) 
emphasis on immigration and free movement of labour. Barak Obama's intervention in April 2016 operated in a different way. Rather than being a model for emulation as in the Canadian and Australian examples, the US as represented by Obama, became part of the global system of governance that Brexiteers saw - not without reason - arrayed against their initiative to get Britain out of the EU. Here their analysis aligned with the right wing of US politics and provided an unusual instance of the British right criticising American policy. Amidst the confusion of the three weeks following the vote, the Anglosphere emerged as a surprise winner, a vision of the future reassuringly anchored in a vision of the past.

Ben Wellings is a Senior Lecturer in Politics and International Relations at Monash University in Melbourne, Australia and Deputy-director of the Monash European and EU Centre. His current research interests focus on the relationship between nationalism, Euroscepticism and the Anglosphere in the United Kingdom. He is the author of English Nationalism and Euroscepticism: losing the peace (Bern: Peter Lang, 2012).

\section{BIBLIOGRAPHY}

ABBOTT, Tony, 'Transcript: Tony Abbott's controversial speech at the Margaret Thatcher Lecture', Sydney Morning Herald, 28 October 2015, http://www.smh.com.au/federal-politics/ political-news/transcript-tony-abbotts-controversial-speech-at-the-margaret-thatcherlecture-20151028-gkkg6p.html\#ixzz3swUz7oo5, accessed 30 November 2015.

BBC NEWS EU REFERENDUM, 'EU referendum: Australia would welcome In vote, says PM Turnbull', 1 May 2016, http://www.bbc.com/news/uk-politics-eu-referendum-36183444, accessed 2 May 2016.

BBC NEWS POLITICS, 'The Daily Politics: Norman Lamont on Leaving the EU', 26 January 2016, http://www.bbc.com/news/uk-politics-35410796, accessed 27 January 2016.

BBC NEWS, 'Brexit would make Britain like Guernsey, says French minister', 18 June 2016, http:// www.bbc.com/news/uk-politics-eu-referendum-36567469, accessed 19 June 2016.

BBC NEWS, 'EU referendum: David Cameron attacks Eurosceptic case ahead of summit', 28 October 2015, http://www.bbc.com/news/uk-politics-34654797, accessed 24 October 2016.

BBC NEWS, 'EU referendum: US wants “strong UK in strong EU”', http://www.bbc.com/news/ukpolitics-eu-referendum-35569134, accessed 14 February 2016.

BBC NEWS, ‘Obama urges UK to stay in European Union’ 24 July 2015, http://www.bbc.com/ news/uk-politics-33647154, accessed 14 February 2016.

BBC NEWS, 'UK stronger in EU, says New Zealand PM', BBC News, 1 April 2016, http:// www.bbc.com/news/uk-politics-eu-referendum-35943388, accessed 2 April 2016.

CADMAN, Andrew, 'Let's quit the EU and join a new club based on the Anglosphere', The Conservative Woman, 28 May 2015, http://www.conservativewoman.co.uk/andrew-cadman-letsquit-the-eu-and-join-a-new-club-based-on-the-anglosphere/, accessed 16 March 2016. 
CANNANE, Steve, 'Brexit: Tory MP slams Turnbull for saying he would welcome the UK remaining in the EU', ABC News, 25 May 2016, http://www.abc.net.au/news/2016-05-26/tory-mp-takes-aimat-turnbull-over-brexit/7446946, accessed 4 July 2016.

COHEN Nick, 'It's a Eurosceptic Fantasy that the Anglosphere Wants Brexit', The Spectator Blogs, 12 April 2016, http://blogs.spectator.co.uk/2016/04/its-a-eurosceptic-fantasy-that-theanglosphere-wants-brexit/, accessed 23 October 2016.

CRUZ, Ted, 'Britain will be at the front of the queue for a US trade deal', The Times, 27 April 2016, http://www.thetimes.co.uk/article/britain-will-be-at-the-front-of-the-queue-for-a-us-tradedeal-vpg93g25r, accessed 28 April 2016.

DAVIS, David, 'Britain would be better off out of the EU - and here's why', Conservative Home, 4 February 2016, http://www.conservativehome.com/platform/2016/02/david-davis-britainwould-be-better-off-out-of-the-eu-and-heres-why.html, accessed 16 March 2016.

EVANS, Gareth, 'The Anglosphere Illusion', Project Syndicate, 18 February 2016, https:// www.project-syndicate.org/commentary/uk-little-global-influence-after-brexit-by-garethevans-2016-02?barrier=true, accessed 23 October 2016.

GLENDAY, James, 'Australia, Canada, NZ and UK support EU-style free movement, new poll says', ABC News, 13 March 2016, http://www.abc.net.au/news/2016-03-13/australia-canada-nzsupport-eu-style-free-movement-poll-says/7242634, accessed 13 March 2016.

GOVE, Michael, 'The Facts of Life Say Leave', 19 April 2016, http://

www.voteleavetakecontrol.org/michael_gove_the_facts_of_life_say_leave, accessed 2 July 2016.

GUARDIAN, 'The Guardian view on the EU debate: it's about much more than migration', The Guardian, 2 June 2016, http://www.theguardian.com/commentisfree/2016/jun/01/the-guardianview-on-the-eu-debate-its-about-much-more-than-migration, accessed 2 June 2016.

HANSARDS PARLIAMENTARY RECORDS, 28 October 2015, column 345.

HEFFER, Simon, 'The Anglosphere Renaissance: Britain's global view in flux', The Interpreter, 17 October 2016, http://www.lowyinterpreter.org/author/Simon\%20Heffer.aspx, accessed 24 October 2016.

HINSLIFF, Gabby, 'As Trudeamania torches the internet, it's time to realise that there is indeed a vision of what a progressive Britain could be. And it's called Canada', Guardian Weekly, 194, 18, 8-14 April 2016: 48.

JOHNSON, Boris, 'Boris Johnson: UK and America can be better friends than ever Mr Obama... if we LEAVE the EU'. The Sun, 22 April 2016, http://www.thesun.co.uk/sol/homepage/news/ politics/7095695/UK-and-America-can-better-friends-than-ever-Mr-Obama-if-we-LEAVE-the-EUsays-Boris-Johnson.html, accessed 26 April 2016.

LEONARD, Mark, 'What would a UK outside the EU look like?' The Guardian, 5 October 2015, https://www.theguardian.com/commentisfree/2015/oct/05/brussels-eurosceptics-british-voterout-lobby, accessed 2 July 2016.

MARDELL, Mark, 'Tory Leadership: Behind the scenes of the Johnson-Gove drama', BBC News, http://www.bbc.com/news/uk-36693200, accessed 24 October 2016.

NATIONAL POPULATION AND TALENT DIVISION, 'Population Figures in Brief', http:// www.nptd.gov.sg/Portals/0/Homepage/Highlights/population-in-brief-2015.pdf, accessed 24 October 2016. 
OTAGO DAILY TIMES, 'EU stronger with Britain - Key', 1 April 2016, http://www.odt.co.nz/news/ politics/378192/eu-stronger-britain-key, accessed 3 April 2016.

SMYTH, Jamie, 'Former Australian premier John Howard backs Britain to leave EU', Financial Times, 7 April 2016: http://www.ft.com/cms/s/0/0abe0092-fbee-11e5-8f41-df5bda8beb40.html, accessed 4 July 2016.

TASKER, John Paul, 'Justin Trudeau steps into 'Brexit' debate, says Britain should stay in EU, CBC News, 19 May 2016, http://www.cbc.ca/news/politics/trudeau-brexit-eu-1.3590404, accessed 3 July 2016.

UK INDEPENDENCE PARTY (2015). Believe in Britain. UKIP Manifesto 2015, http://www.ukip.org/ manifesto2015, accessed 1 December 2015.

UK INDEPENDENCE PARTY (2015). Out of the EU and Into the World. Brussels, Europe of Freedom and Democracy Group.

WATT, Nicholas, 'Michael Gove and five other cabinet members break ranks with the PM over EU', The Guardian, 21 February 2016, http://www.theguardian.com/politics/2016/feb/20/ michael-gove-and-five-other-cabinet-members-break-ranks-with-pm-over-eu, accessed 23 February 2016.

WELLINGS, Ben and BAXENDALE, Helen. 2015. 'Euroscepticism and the Anglosphere: traditions and dilemmas in contemporary English nationalism', Journal of Common Market Studies, 53, 1: 123-39.

YOUGOV, 'Which Countries Should We Focus on For Trade Deals?' 17 September 2016, https:// yougov.co.uk/news/2016/09/17/which-countries-should-uk-prioritise-post-brexit-t/, accessed 24 October 2016.

\section{NOTES}

1. BBC NEWS, 'Brexit would make Britain like Guernsey, says French minister', 18 June 2016, http://www.bbc.com/news/uk-politics-eu-referendum-36567469, accessed 19 June 2016.

2. UK INDEPENDENCE PARTY (2015). Believe in Britain. UKIP Manifesto 2015, http:// www.ukip.org/manifesto2015, accessed 1 December 2015.

3. UK INDEPENDENCE PARTY (2015). Out of the EU and Into the World, Brussels, Europe of Freedom and Democracy.

4. CADMAN, Andrew, 'Let's quit the EU and join a new club based on the Anglosphere', The Conservative Woman, 28 May 2015, http://www.conservativewoman.co.uk/andrewcadman-lets-quit-the-eu-and-join-a-new-club-based-on-the-anglosphere/, accessed 16 March 2016.

5. DAVIS, David, 'Britain would be better off out of the EU - and here's why', Conservative Home, 4 February 2016,

http://www.conservativehome.com/platform/2016/02/david-davis-britain-would-bebetter-off-out-of-the-eu-and-heres-why.html, accessed 16 March 2016.

6. WATT, Nicholas, 'Michael Gove and five other cabinet members break ranks with the PM over EU', The Guardian, 21 February 2016, http://www.theguardian.com/ politics/2016/feb/20/michael-gove-and-five-other-cabinet-members-break-ranks-withpm-over-eu, accessed 23 February 2016. 
7. BBC NEWS, 'EU referendum: US wants “strong UK in strong EU”',

http://www.bbc.com/news/uk-politics-eu-referendum-35569134, accessed 14 February 2016.

8. TASKER, John Paul, 'Justin Trudeau steps into 'Brexit' debate, says Britain should stay in EU, CBC News, 19 May 2016' http://www.cbc.ca/news/politics/trudeau-brexiteu-1.3590404, accessed 3 July 2016.

9. BBC NEWS, 'UK stronger in EU, says New Zealand PM', BBC News, 1 April 2016, http:// www.bbc.com/news/uk-politics-eu-referendum-35943388, accessed 2 April 2016.

10. BBC NEWS EU REFERENDUM, 'EU referendum: Australia would welcome In vote, says PM Turnbull', 1 May 2016, http://www.bbc.com/news/uk-politics-eureferendum-36183444, accessed 2 May 2016.

11. BBC NEWS EU REFERENDUM, 'EU referendum: Australia would welcome In vote, says PM Turnbull', 1 May 2016, http://www.bbc.com/news/uk-politics-eureferendum-36183444, accessed 2 May 2016.

12. BBC NEWS, 'EU referendum: US wants "strong UK in strong EU",

http://www.bbc.com/news/uk-politics-eu-referendum-35569134, accessed 14 February 2016.

13. OTAGO DAILY TIMES, 'EU stronger with Britain - Key', 1 April 2016' http:// www.odt.co.nz/news/politics/378192/eu-stronger-britain-key, accessed 3 April 2016.

14. COHEN Nick, 'It's a Eurosceptic Fantasy that the Anglosphere Wants Brexit', The Spectator Blogs, 12 April 2016, http://blogs.spectator.co.uk/2016/04/its-a-euroscepticfantasy-that-the-anglosphere-wants-brexit/, accessed 23 October 2016.

15. EVANS, Gareth, 'The Anglosphere Illusion', Project Syndicate, 18 February 2016, https://www.project-syndicate.org/commentary/uk-little-global-influence-after-brexitby-gareth-evans-2016-02?barrier=true, accessed 23 October 2016.

16. BBC NEWS, 'Obama urges UK to stay in European Union' 24 July 2015, http://www.bbc.com/news/uk-politics-33647154, accessed 14 February 2016.

17. BBC NEWS, 'Obama urges UK to stay in European Union' 24 July 2015, http://www.bbc.com/news/uk-politics-33647154, accessed 14 February 2016.

18. CRUZ, Ted, 'Britain will be at the front of the queue for a US trade deal', The Times, 27 April 2016: http://www.thetimes.co.uk/article/britain-will-be-at-the-front-of-the-queuefor-a-us-trade-deal-vpg93g25r, accessed 28 April 2016.

19. JOHNSON, Boris, 'Boris Johnson: UK and America can be better friends than ever Mr Obama... if we LEAVE the EU'. The Sun, 22 April 2016, http://www.thesun.co.uk/sol/ homepage/news/politics/7095695/UK-and-America-can-better-friends-than-ever-MrObama-if-we-LEAVE-the-EU-says-Boris-Johnson.html, accessed 26 April 2016.

20. WELLINGS, Ben and BAXENDALE, Helen, 'Euroscepticism and the Anglosphere: traditions and dilemmas in contemporary English nationalism', Journal of Common Market Studies, 53, 1, 2015, pp. 123-39.

21. CANNANE, Steve, 'Brexit: Tory MP slams Turnbull for saying he would welcome the UK remaining in the EU', ABC News, 25 May 2016, http://www.abc.net.au/ news/2016-05-26/tory-mp-takes-aim-at-turnbull-over-brexit/7446946, accessed 4 July 2016. 
22. GLENDAY, James, 'Australia, Canada, NZ and UK support EU-style free movement, new poll says', ABC News, 13 March 2016, http://www.abc.net.au/news/2016-03-13/australiacanada-nz-support-eu-style-free-movement-poll-says/7242634, accessed 13 March 2016.

23. SMYTH, Jamie, 'Former Australian premier John Howard backs Britain to leave EU', Financial Times, 7 April 2016, http://www.ft.com/cms/s/0/0abe0092-fbee-11e5-8f41df5bda8beb40.html, accessed 4 July 2016.

24. GOVE, Michael, 'The Facts of Life Say Leave', 19 April 2016, http:// www.voteleavetakecontrol.org/michael_gove_the_facts_of_life_say_leave, accessed 2 July 2016.

25. ABBOTT, Tony, 'Transcript: Tony Abbott's controversial speech at the Margaret Thatcher Lecture', Sydney Morning Herald, 28 October 2015,

http://www.smh.com.au/federal-politics/political-news/transcript-tony-abbotts-

controversial-speech-at-the-margaret-thatcher-lecture-20151028-

gkkg6p.html\#ixzz3swUz7oo5, accessed 30 November 2015.

26. GUARDIAN, 'The Guardian view on the EU debate: it's about much more than migration', The Guardian, 2 June 2016, http://www.theguardian.com/ commentisfree/2016/jun/01/the-guardian-view-on-the-eu-debate-its-about-much-morethan-migration, accessed 2 June 2016.

27. BBC NEWS, 'EU referendum: David Cameron attacks Eurosceptic case ahead of summit', 28 October 2015, http://www.bbc.com/news/uk-politics-34654797, accessed 24 October 2016.

28. HANSARDS PARLIAMENTARY RECORDS, 28 October 2015, column 345.

29. HINSLIFF, Gabby, 'As Trudeamania torches the internet, it's time to realise that there is indeed a vision of what a progressive Britain could be. And it's called Canada', Guardian Weekly, 194, 18, 8-14 April 2016: 48.

30. BBC NEWS POLITCS, 'The Daily Politics: Norman Lamont on Leaving the EU', 26 January 2016, http://www.bbc.com/news/uk-politics-35410796, accessed 27 January 2016.

31. LEONARD, Mark, 'What would a UK outside the EU look like?' The Guardian, 5 October 2015, https://www.theguardian.com/commentisfree/2015/oct/05/brussels-euroscepticsbritish-voter-out-lobby, accessed 2 July 2016.

32. NATIONAL POPULATION AND TALENT DIVISION, 'Population Figures in Brief', http:// www.nptd.gov.sg/Portals/0/Homepage/Highlights/population-in-brief-2015.pdf, accessed 24 October 2016.

33. MARDELL, Mark, 'Tory Leadership: Behind the scenes of the Johnson-Gove drama', BBC News, http://www.bbc.com/news/uk-36693200, accessed 24 October 2016.

34. YOUGOV, 'Which Countries Should We Focus on For Trade Deals?' 17 September 2016, https://yougov.co.uk/news/2016/09/17/which-countries-should-uk-prioritise-post-brexit-t/, accessed 24 October 2016.

35. HEFFER, Simon, 'The Anglosphere Renaissance: Britain's global view in flux', The Interpreter, 17 October 2016, http://www.lowyinterpreter.org/author/Simon\%20Heffer.aspx, accessed 24 October 2016. 


\section{ABSTRACTS}

The Anglosphere was one of the surprise winners of the 2016 referendum campaign. As an explicitly stated concept it appeared early on in the campaign but soon faded from view. But where it did play a part in the campaign was less as a unitary concept but more in its constituent parts: sometimes as an example to emulate and at other times as another layer of global interference to reject. The Anglosphere assumed increased importance after the shock result as Leave leaders sought to elaborate an alternative to Europe that they seemed not to have developed deeply before 24 June.

L'Anglosphère a été l'un des vainqueurs inattendus de la campagne référendaire de 2016. En tant que concept explicite, l'Anglosphère a surgi très tôt dans la campagne mais a rapidement disparu. Toutefois, si elle a joué un véritable rôle dans la campagne, c'est moins en tant que concept unitaire que par ses éléments constitutifs : parfois comme un exemple à suivre, et à d'autres moments comme une nouvelle illustration d'une ingérence internationale à rejeter. L'Anglosphère a pris une importance accrue après le choc du résultat du référendum alors que les leaders du camp du "Leave" tentaient d'élaborer une alternative à l'Europe qu'ils ne semblaient pas avoir beaucoup développée avant le 24 juin.

\section{INDEX}

Mots-clés: Brexit, Obama, système d'immigration à points, CETA.

Keywords: Brexit, Anglosphere, Obama, points-based immigration system, CETA.

\section{AUTHOR}

\section{BEN WELLINGS}

Monash University, Melbourne, Australia 